\title{
The Securitization of the European Migrant Crisis - Evidence From Bulgaria and Hungary (2015-2017)
}

\author{
Tatiana P. Rizova \\ Correspondence: Tatiana P. Rizova, Department of Political Science, Christopher Newport University, 1 Avenue of the \\ Arts, Newport News, VA 23188, U.S.A. E-mail: tatiana.rizova@cnu.edu
}

Received: August 27, 2019 Accepted: November 22, 2019 Online Published: December 3, 2019

doi:10.5539/res.v11n4p78

URL: https://doi.org/10.5539/res.v11n4p78

\begin{abstract}
Conflicts in Afghanistan, Iraq, and Syria over the past fifteen years have produced the largest waves of displaced people and refugees since World War II. As European Union (EU) leaders braced for an influx of thousands of people fleeing from these conflicts, they faced pressures to revisit and modify legal rules that left countries in Southeastern Europe and the Mediterranean unable to cope with a crisis of unprecedented proportions in the twenty-first century. While the logistical challenges of this humanitarian disaster threatened to undermine Southeastern and Mediterranean states' capacity, multiple terrorist attacks across Europe magnified the security concerns of EU leaders. This paper compares how two of the European Union's newest member states - Bulgaria and Hungary - have tackled the migrant crisis and assesses the impact of security concerns on their refugee policies. Some of the responses of these countries' governments were similar - both governments mandated the erection or extension of physical barriers to impede migrants' entry on their countries' territory. While the Bulgarian government took cues from the rhetoric and actions of key EU leaders such as Angela Merkel, the Hungarian government continuously antagonized EU leaders and declined to cooperate with their proposed multi-lateral strategies of handling the migrant crisis. Decisions taken by the two governments were, to some extent, dictated by security concerns. The rhetoric of the Hungarian government, however, contained stronger nationalist overtones than that of the Bulgarian government. Hungary's Prime Minister Viktor Orbán and his right-wing government led an anti-migrant and anti-refugee campaign that sought to exclude foreign nationals due to the patent incompatibility of their cultural values with those of Hungary's nationals. On the other hand, the rhetoric of Bulgaria's Prime Minister - Boiko Borisov - was more dualistic and contradictory. His policy statements to the foreign press or at EU summits reflected the general sentiment of the top EU brass, whereas statements made to the Bulgarian media focused more specifically on security concerns and were far more critical of the foreign nationals attempting to enter Bulgaria's territory. Moreover, the security-focused rhetoric and actions of the government became more strident immediately before and after the Bulgarian presidential elections of November 2016, which led to the resignation of Borisov's cabinet. Political parties in Bulgaria, including Borisov's GERB party have increasingly become critical of refugees living in Bulgaria's admission centers. Borisov's government even extradited a group of Afghan asylum seekers due to their involvement in a riot at one of the refugee admission centers. This study is based on a content analysis of statements made by Bulgarian and Hungarian government officials and media coverage in several Bulgarian and Hungarian news publications between 2015 and 2017.
\end{abstract}

Keywords: Bulgaria, Copenhagen School, Hungary, refugees, securitization

\section{Introduction}

As civil conflict ravaged Syria, and Afghanistan and Iraq struggled to sustain peace and newly fledged democratic institutions, Europe braced for a humanitarian crisis of unprecedented proportions. More than a million people fled from areas of conflict and sought refuge in Europe in 2015 alone; the majority of these refugees were Syrian nationals who had been driven away from their homes by a complex set of internal conflicts involving state and non-state actors. In the first eight months of 2017, nearly 120,000 people risked their lives during a treacherous journey across the Mediterranean Sea and 2,420 drowned (UNHCR - Europe Situation, 2017). While the migrant and refugee crisis has subsided since its peak in 2015, humanitarian concerns over the well-being of the migrants and refugees remain. So do concerns over the possible economic and security implications of the arrival of thousands of foreign nationals at Europe's borders who seek safety and asylum. Perceptions and rhetoric concerning refugees and migrants are critical to understanding the degree of restrictiveness that state authorities exercise in their decisions how to protect their national borders. As the UN Special Rapporteur on Refugees and Terrorism recently concluded, "the current discourse focuses on migration as a fuel for terrorism, which has led to migration policies being viewed overwhelmingly through the 
prism of security" (Assembly, 2016). The "prism of security" is the product of human agency, the outcome of intersecting discourses on refugees and migrants, which cast them in a negative light and equate them with terrorist fighters.

This paper analyzes the responses of the Bulgarian and Hungarian governments to the Syrian refugee crisis between 2015 and 2017. It challenges traditional security theories about what constitutes a security challenge. After examining the evidence about the types and magnitude of the security threats posed by migrants and refugees who were fleeing to Europe, the paper establishes that traditional security theories do not provide an adequate understanding and explanation of the refugee policies adopted by the Hungarian and Bulgarian governments during this time period. Neither of the two countries was a final destination for migrants and asylum seekers, yet their governments framed the situation at their borders as a security crisis. The paper relies on the framework of the Copenhagen School of security studies and argues that state responses to the refugee and migrant crisis, as in the cases of Bulgaria and Hungary, were motivated by concerns over the cultural identity, cohesion, and societal integrity in their countries and the perception of terrorist threat stemming from the migrant crisis. The paper consists of the following sections - overview of the refugee crisis and its impact on Hungary and Bulgaria, assessment of the evidence of security threats posed by the migrant and refugee crisis, and analysis of the interactions of political elites, the media, and social groups in the construction of the refugee crisis as a security threat.

The argument in the paper distinguishes between two elements of securitization - securitization as a speech act, which draws on the literature of the Copenhagen school of security studies - and securitization as a political practice and a set of policy outcomes. Political elites employ rhetorical tools to mobilize public support for their political agenda in the realm of security just like in any other policy area. It is important to differentiate between rhetoric and political outcomes, however. While discussing issues of migration and refugee flows by conjuring up images of criminality, disease, violence and chaos could prove useful tools of garnering public support for decisive action, it does not necessarily mean that rhetoric will translate into policy outcomes. Viktor Orbán's claims that Syrian refugees would jeopardize European values and that all terrorists were migrants, while divorced from reality, helped him convince Hungarian legislators to pass restrictive laws on refugee admissions. The purpose of this paper is to analyze the causal mechanisms, which link the securitization of the migrant and refugee crisis as a speech act to actual policies that reflect this securitization - policies that allow border authorities to push migrants and refugees back into third countries or enable the detention of asylum seekers or embroil them in bureaucratic hurdles to jeopardize their asylum cases.

\section{Traditional vs. Critical Conceptions of Security}

As Gjorv (2012, p. 839) has argued, the "traditional' concept of security is embedded in an "epistemology of fear." "An epistemology of fear grounds itself in attempts to know and objectify death, to make it concrete, so that threats and enemies can be identified," he claims (p. 839). This traditional concept of security is state-centric as it focuses on the state as the actor that not only identifies the source of threat, but is also charged with marshalling resources and devising strategies to confront and tackle internal or external threats. According to neo-realists, "security is the most important goal a state can have... Just as teams compete to be champions, so states compete for security" (Baldwin, 1997, p. 10). As neo-realist scholar Kenneth Waltz has observed "in anarchy, security is the highest end" (Waltz, 1979, p. 126). Realist and neo-liberal institutionalist approaches, which rely on this traditional definition of security, have been criticized for assuming that threats are objective and exogenously defined. Dealing with threats is the exclusive domain of the state and the military as its defense arm. Based on these conventional approaches, the object of the threat (the referent object), is the state rather than sub-state, non-state or supra-state units. Thus, the state is both the referent object and the actor responsible for formulating and executing security policy. Non-traditional approaches, on the other hand, are based on the premise that security is defined endogenously and security threats are constructed through interactions between state and non-state actors rather than being objective and exogenously defined. Critics of traditional views of security suggest that multiple groups within the state ('securitizing actors') influence the definition of a security threat, and these include "political leaders, bureaucracies, governments, lobbyists, and pressure groups" (Buzan \& Hansen, 2009, p. 214). The referent object, based on critical approaches to security, and the Copenhagen School of security studies more specifically, may be the state or other entities such as society and national identity (Buzan \& Hansen, 2009, p. 213). Regardless of which theoretical perspective one adopts, a comprehensive definition of security should accomplish the following - "specify security with respect to the actor whose values are to be secured, the values concerned, the degree of security, the kinds of threats, the means for coping with such threats, the costs of doing so, and the relevant time period" (Baldwin, 1997, p. 17).

The causal narrative presented by scholars of the Copenhagen School helps explain precisely how and why security rhetoric translates into laws, policies, and practices that affect security outcomes. Buzan and Weaver argue that the securitization of a given issue leads to extraordinary measures because it compels policy makers to respond quickly in order to diminish a security threat. This securitization narrative also tends to generate the necessary public support for 
such extraordinary measures. Securitizing an issue through speech acts, however, does not automatically lead to a piece of legislation whose purpose is to alleviate a presumed security threat. The key insight of the Copenhagen School of Security is that no event or issue in itself constitutes a security threat, that "anything could be constructed as one" (Buzan, Waever, \& de Wilde). Security then is defined as "the sovereign authority's ability to legitimate the use of emergency measures in the face of exceptional threats" (Hansen, 2012). Scholars from this school of thought have argued that "what is central to security analysis is thus understanding the process through which particular 'threats' manifest themselves on the political agenda" (Buzan \& Hansen, 2009). This paper argues that in addition to understanding how threats are perceived and expressed as a speech act and how they become incorporated in the security agenda of a government, we ought to analyze how multiple security threats are prioritized and transformed from an agenda item into a policy outcome.

The securitization of refugee flows is typically associated with restrictive policies of admission of foreign nationals and increased scrutiny in the review and granting of protected or asylum status to these individuals. Why did governments in Eastern and Central Europe choose to treat refugees as a security threat rather than the victims of a humanitarian crisis? What type of security threat did political elites and the media in these countries identify in their accounts of the refugee crisis?

\section{The Politics of Fear}

In July 2017, the Norwegian anti-immigrant group Fatherland First posted the image of an empty bus and decried the state of Norwegian society which, in the eyes of the group, was being swallowed by Muslim immigrants (Taylor, 2017). The group had mistaken the colorful empty bus seats for a group of Muslim women wearing burqas. Within hours of the posting one hundred people had left comments claiming that the empty bus seats could really be terrorists hiding their weapons under the burqas and expressed fear over the dangers lurking underneath the imaginary female garments. Some even called for a ban on burqas to eliminate the looming terrorist threat. An overwhelming number of Norwegian readers also commented on the inanity of the xenophobes who had mistaken the empty bus seats for burqas and openly mocked them on several internet fora. The incident is a perfect example of how security threats can be constructed where they simply do not exist. In the case of refugees, for example, much of the commentary and discussion in the media have focused on their country of origin or religion "to the detriment of an objective evaluation of the reasons why they have to flee their countries of origin" (D'Appollonia, 2017). One of the key elements of securitization as a speech act is the description of the type of threat posed by a given phenomenon and a reference to the entity that is the subject of that threat (the referent object). The referent object is context-driven and socially constructed through references made to the security threat in elite speeches, media coverage, and public discourse. The referent object could include the state, specific groups within a nation-state, the nation or even more abstract and intangible entities such as national or cultural identity. The public perception of threat and the intensity of that threat varies depending on how that threat has been framed and who or what the referent object is. The security literature notes, for instance, that in the aftermath of the 9/11 attacks in the United States, numerous policy changes were introduced that imposed restrictions on immigration in the United States and the United Kingdom. The referent object in these new immigration and security policies was not just the nation and the state, but U.S. political and cultural values. As D'Appollonia states, "terrorism was portrayed as a threat not only to people's lives but also to their values, freedom, and economic and social welfare" (D'Appollonia, 2012).

How was the issue of the refugee/migrant crisis framed by political elites and the media in Eastern and Central Europe? Who or what was the referent object in describing the sources of security threats emanating from the refugee and migrant crisis? The present study analyzes the securitization of the refugee and migrant crisis by relying on textual analysis of the refugee crisis in two countries in the region - Bulgaria and Hungary - between 2015 and 2017. The study focuses on an analysis of media coverage during this time period in select publications accessed through the Newsbank database, which provides access to multiple international media sources. The keywords used in the search were refugee crisis and migrant crisis. Based on these search parameters, I analyzed forty-five news reports by the Bulgarian Telegraph Agency and articles published in the Hungarian center-left daily Népszabadság. The coding decisions are discussed in Appendix 1 and tables 1 and 2 present a summary of the analysis.

Several authors have conducted content analysis of media sources in several countries that were affected by the migrant and refugee crisis caused by the Syrian conflict (Caviedes, 2017; de Medeiros \& Bernardes, 2016; Herta, 2017). Textual analysis of media sources provides an insight into important political debates that were at the top of the political agenda or were considered relevant by the media and the public. As Caviedes (2017, p. 296) has observed, "the media occupies a unique position within society due not only to the perception that it is more objective than the afore-mentioned political actors [political parties, research institutes, or the government itself], and therefore able to offer an authoritative view concerning the true relationship between immigration and security (Bigo 2002: 76), but also because of its power to transmit this message effectively to a broader audience where it assumes the position of a hegemonic 
discourse." In his textual analysis, Caviedes examines the presence of five general themes in the news articles that portray immigration issues as a source of physical threat, crime, border insecurity, labor market problems, and asylum costs. News articles are coded as containing one or more of these themes and therefore themes are not treated as mutually exclusive, but rather as complementary.

The analysis presented in this work differs from Caviedes's approach in several important respects. First, it is more comprehensive in scope as it focuses not only on the refugee and migrant crisis issues covered in news articles and reports, but also on the securitizing agent (be it a government official, an international political agent or the media source itself), the referent object (which group, idea or entity is considered the object of the security threat), and includes a more comprehensive list of referent objects (cultural identity, for instance, can be a bona fide referent object). Second, it is not based on a dichotomy between physical threat, crime, and border issues on the one hand and economic issues on the other. Concerns about unemployment, for instance, could lead to securitization of a refugee/migrant crisis, which could be framed as a source of threat to economic security, even if there are no concerns about physical and border security. Third, the analysis presented here does incorporate not only the media as a securitizing actor, but other actors such as foreign policy makers and important international agents such as representatives of international law enforcement or security agencies or the European Union. Finally, the current research paper also assesses the importance of the refugee and migrant crisis as a potential source of security threat vis-à-vis other possible sources of security threat. Thus, the analysis also examines how policy makers prioritize other security threats in the context of the refugee and migrant crisis.

This research focuses on Bulgaria and Hungary whose governments had to contend with various aspects of the migrant and refugee crisis in the aftermath of the Syrian civil conflict. Bulgaria is the southern frontier of the European Union, along with Greece; Greece was deeply affected by the initial waves of refugees trying to reach Europe by relying on several sea routes that would take them to the Greek islands in the Aegean Sea. Refugees also sought to reach Europe's interior by crossing the border between Bulgaria and Turkey and continuing their journey to Western European countries. Many refugees headed towards Hungary using it as a transit zone on their way to more appealing EU destinations such as Germany and Sweden or Denmark and the United Kingdom. In 2015, which marked the peak of the migrant crisis, the Hungarian asylum system was certainly under duress given the high number of asylum applications per 100,000 Hungarians. Hungary topped the list of countries with the highest number of asylum applications per 100,000 native inhabitants; there were 1,799 asylum applications in Hungary as opposed to 283 in Bulgaria. The average number of asylum applications in the European Union stood at 260; both Bulgaria and Hungary had received more applications than the EU average (Bordermonitoring Bulgaria, 2017; UNHCR: Europe Situation, 2017).

Table 1. Themes covered in Bulgarian and Hungarian news articles about the migrant and refugee crisis (2015-2017)

\section{Theme}

Proportion of articles that

contain theme $(\mathrm{N}=45)$

\begin{tabular}{ll}
\hline \multicolumn{2}{l}{ Policy Variables } \\
\hline Policies that emphasize changes to asylum procedures & $4.4 \%$ \\
\hline Policies that emphasize detention procedures & $6.7 \%$ \\
\hline Policies that emphasize expulsions & $6.7 \%$ \\
\hline Policies that emphasize construction of physical barriers & $42.2 \%$ \\
\hline \multicolumn{2}{c}{ Threat Variables } \\
\hline Refugees as a source of threat to the economy & $13.3 \%$ \\
\hline Refugees as a source of terrorist threat & $31.1 \%$ \\
\hline Refugees as a source of cultural threat & $15.6 \%$ \\
\hline
\end{tabular}

The preliminary data collected from Bulgarian and Hungarian media sources indicate that most of the media and policy discussions revolved around the construction of physical barriers and deterring refugees and migrants from entering the two countries altogether. The articles focused on multiple referent objects as the potential targets or victims of security threats - the economy, society, and culture or cultural identity. Treating refugees as a source of terrorist threat dominated the articles that I examined, although the economic and cultural identity were also important considerations in securitizing the crisis. 
Table 2. Country-level proportion of news articles that discuss different policies and sources of threat stemming from the refugee crisis (2015-2017)

\begin{tabular}{lll}
\hline & Bulgaria & Hungary \\
\hline$\%$ Articles (asylum procedures) & $0 \%$ & $9.5 \%$ \\
\hline$\%$ Articles (detention procedures) & $4.2 \%$ & $9.5 \%$ \\
\hline$\%$ Articles (expulsions) & $4.2 \%$ & $9.5 \%$ \\
\hline$\%$ Articles (physical barriers) & $50 \%$ & $33.3 \%$ \\
\hline$\%$ Articles (economic threat) & $12.5 \%$ & $14.3 \%$ \\
\hline$\%$ Articles (terrorist threat) & $16.7 \%$ & $47.6 \%$ \\
\hline$\%$ Article (cultural threat) & $8.3 \%$ & $23.8 \%$
\end{tabular}

Upon examining the country-level data, one can discern the following patterns. First, the media sources reflect a greater emphasis on physical barriers in the case of Bulgaria, though the Hungarian sources also stressed the importance of building a fence to protect the territorial integrity of Hungary. Sources in both countries focused on refugees as a source of economic, terrorist, and cultural threat. The treatment of refugees as a source of terrorist threat seems to be a leading theme in both cases, particularly in the case of Hungary. The second most important theme in the two countries is refugees as an economic threat in Bulgaria's case and refugees as a cultural threat in Hungary's case. The current study is based on limited data, which imposes limitations on the validity and generalizability of the conclusions. An expanded version of this data analysis will include more comprehensive textual analysis of news articles and policy statements made by political leaders in both countries.

The data on Hungary presented in this paper are consistent with the results of a more comprehensive study based on an analysis of several online media sources in 2015 during the height of the refugee crisis in Central Europe. The Hungarian government issued multiple statements in which refugees were described as "criminals, terrorist threats, carrying the risk of epidemics" (Simonovits \& Bernat, 2016, p. 136). The mayor of Budapest's 8th district, for instance, posted the following statement on a public forum: "They build tents, they make fires in the park, they litter, they go crazy, they steal, they stab, they destroy. There have never been so much human feces on public property" (Simonovits \& Bernat, 2016, p. 129).

\section{The Politics of Fear and Exclusion}

\subsection{The Politics of Fear and Exclusion in Hungary}

Observers have noted that one of the primary motivations behind Hungary's restrictive immigration and refugee admission policies is the government's mission to protect the cultural identity of their country. Hungary's Prime Minister himself "describes himself as the protector of the Hungarian nation, and in a similar way, he monopolizes the role of the protector of Europe at an international level by using enemy images he invented such as representatives of the bygone liberal era, immigrants, and Brussels bureaucrats" (Népszabadság, 2015). Several themes related to the refugee and migrant crisis dominated the pages of the Hungarian media in 2015 and 2016 - the construction of a physical barrier to stem the flow of people toward Hungarian territory, the fear that Hungary's Christian culture is the victim of a Muslim attack, and an emphasis on instruments of direct democracy (i.e. referenda) to seek permanent solutions the refugee and migrant crisis. In an interview with Népszabadsag, the Hungarian Minister of Trade and Foreign Affairs - Péter Szijjártó - falsely claimed that Hungary had admitted thousands of Egyptian Coptic refugees who had faced persecution in Egypt for their religious beliefs. When the interviewing reporters challenged the minister to provide details about these refugees, he declined to do so (Csuhaj \& Horváth, 2015). Szijjártó also commended the Slovakian government for exercising better judgement in its migrant and refugee policies given its willingness to accept only refugees of Christian background. Journalist Miklós Hargitai wrote a damning editorial in which he excoriated the media and the Hungarian government for paying disproportionate attention to the migrant crisis compared to other political and economic issues. Hargitai expressed his indignation at the framing of the migrant and refugee crisis as a cultural issue in which the source of danger to Hungarian society stemmed from "newcomers who have brown skin, look culturally remote and aggressive, and are hatching plans to break through fences, swim across border rivers, and carry out other frightening acts from dawn to dust [sic]" (Hargitai, 2016).

The anti-refugee rhetoric of far right-wing Hungarian politicians has also culminated in public marches and public statements whose purpose was to sow fear among the Hungarian population. In July 2015, the Deputy Chairman of the far right-wing political party Jobbik, which is second in its parliamentary seat share to the leading Fidesz (Civic Alliance), made the following statement at a march in Debrecen: "We should prepare for self-defence. I am telling this to those who 
think that they can save their skin. After the Debrecen unrest, riots may break out anywhere; kind Negro gentlemen will set off with a machete, and then, rich suburban residents will be surprised" (Népszabadság, 2015). Meanwhile the Jobbik's parliamentary deputy, Gergely Kulcsar, urged the government to close all refugee camps in Hungary (Népszabadság, 2015). Another Jobbik leader and participant in the march, Muranyi, joined in the criticism of the Hungarian government and European Union leadership by claiming that the real victims of the refugee crisis were "the Europe of Christian nations, European civilization, and the culture of white people" (Népszabadság, 2015). In March 2016, Jobbik organized its third "national demographic" conference whose topic was the "connections between a dramatic Hungarian and European population decline and illegal immigration" (Czene, 2016). Speakers at the conference bemoaned the sad state of affairs in Europe where the "white human race" was in danger of extermination and would be overcome by "Africans, Muslims, and Gypsies" (Czene, 2016).

Anti-immigration and anti-refugee sentiments have been the staple of the Hungarian government's rhetoric since the early days of 2015. Prime Minister Viktor Orbán has successfully kept the image of the belligerent anti-Christian vagabond migrant and refugee alive in his public addresses. In an anniversary speech he gave in March 2016, Orbán juxtaposed "Europe's Christian and pro-freedom identity" and "mass migration" claiming that stemming mass migration is the key to preserving Europe's Christian pro-freedom values (Népszabadság, 2016).

Newspaper coverage featured predominantly negative stories about refugees and migrants portraying them as terrorists and criminals. In September 2015, for instance, a report surfaced about Syrian citizen Ahmad H who was apprehended by Hungarian police for organizing and leading a migrant protest at the Röszke border crossing between Hungary and Serbia. The report claimed that the 39-year-old man had seven passports and had links to the Islamic fundamentalist organization Tablighi Jamaat (Fekete, 2015).

\subsection{The Politics of Fear and Exclusion in Bulgaria}

There are some interesting parallels between the rhetoric of Bulgaria's and Hungary's political leaders. The predominant themes in news reports and statements made by cabinet members typically reflect the perception of the migrant and refugee crisis as a source of economic, physical, and cultural threat. The solutions advanced by the two countries' political leaders have also included border closures, the erection of walls or fences, expulsions, and changes to asylum regulations. Bulgaria's premier - Boyko Borisov - for instance has discussed the Syrian refugee crisis in political, economic, and cultural terms. At a meeting held in Bulgaria in 2015, he expressed his concerns about the duration of the crisis, the ability of the government to integrate refugees and the scarcity of economic opportunities in Bulgaria (BTA, 2015). He also pointed out that refugees from countries such as Iraq and Afghanistan might be difficult to integrate, which alluded to the government's preoccupation with the refugees as a source of cultural threat. One of the themes that was far more common in statements made by Bulgarian politicians compared to their Hungarian counterparts is the notion that the refugee crisis ought to be resolved at the source.

Bulgaria is one of the most economically troubled EU member states. Given its location in the heart of the Balkan Peninsula, it is a major gateway to Europe and a direct transit point for migrants and refugees arriving from the Middle East through Turkey. There are few employment opportunities, which makes the country a less appealing destination for permanent settlement than other EU member states. Even though most migrants and refugees are only interested in entering the country so that they can continue their journey to Central and Western Europe, the fact that Bulgaria is the European Union's eastern frontier has made it imperative that the government secure its borders effectively. In 2014 the Bulgarian government erected a barbed wire fence equipped with a sophisticated surveillance system that was meant to stem the flow of illegal migrants and refugees who were trying to cross the Bulgarian-Turkish border (BG Novinite, 2014). In 2016, in spite of clear evidence that fewer migrants and refugees were using Bulgaria as a transit point, the Bulgarian government announced that it had budgeted 35 million Bulgarian leva to extend the fence in an attempt to boost border security (Dnevnik, 2016). Human rights organizations have criticized Bulgarian authorities for preventing refugees from gaining entry into the country and pushing them back into Turkey. In its 2014 annual report, Human Rights Watch revealed some of the most grievous human rights violations of the Bulgarian border authorities. Migrants and refugees who were trying to cross the Turkish-Bulgarian border reported that they had been pushed back into Turkey (Gall, 2015). Some of the migrants and refugees who were interviewed by Human Rights Watch also alleged that they had been beaten by the border authorities or that they had been bitten by border dogs and detained for attempting to cross the border illegally (Human Rights Watch, 2016). Human Rights Watch documented at least 44 instances of pushbacks of 519 people at the Bulgarian-Turkish border between 2013 and 2015 (Gall, 2015). Detention has indeed become a common practice at Bulgaria's borders with Turkey and Serbia. Based on a report by the Center for Legal Aid "Voice in Bulgaria," migrants "are portrayed as a national security threat and criminals, and detention practices are often used as summary punitive measures against migrants in the name of the protection of the public interest." Based on statistics gathered by the Center for Legal Aid (CLA) and the Bulgarian Lawyers for Human Rights (BLHR), the majority of the migrants detained at border crossings came from conflict zones in the Middle East. In 2015, for instance, 31,281 migrants were apprehended, 
and most of them were of Syrian, Afghani and Iraqi origin (Gall, 2015).

Human rights abuses of migrants and refugees who are apprehended by authorities at Bulgarian borders are rampant and have been in the media spotlight for several years now. However, the typical perpetrators of human rights violations are not only representatives of security agencies, but also smugglers and members of local vigilante groups. There have been multiple reports of corruption among border and police authorities who have been accused of taking bribes from smugglers of migrants and refugees (Papakochev, 2016). Smuggling is such a lucrative illegal activity that some members of law enforcement are tempted to accept bribes that substantially exceed their monthly salary. Human rights organizations have been reporting on the human rights abuses that occur frequently at the Bulgarian borders for several years now. The most common grievances that such reports document include beatings, the expropriation of documentation, money, and other valuables, pushbacks without proper registration, detentions in temporary and long-term facilities (Belgrade Center for Human Rights, 2016). While Oxfam and Human Rights Watch, among others, have been very critical of the violent practices of the Bulgarian border authorities, politicians such as former British Prime Minister David Cameron have commended them for being effective guardians of Europe's borders (Strickland, 2015).

The Bulgarian government and anti-corruption agency have found it challenging to combat bribery and other forms of corruption along the border. The predicament of the migrants and refugees is exacerbated by the rise of vigilante groups, self-styled "migrant hunters" or "citizen protection organizations," whose members roam the areas around the border and engage in the illegal detention of migrants (Bulgarian Helsinki Committee, 2016). Corruption among border authorities and police in Bulgaria exemplifies state failure. When border authorities fail to address the needs of refugees adequately by providing resources for their safe passage to refugee facilities, they put refugees at risk to become the victim of another group of mercenaries - vigilante migrant hunters. The reports of migrant hunters scouring the areas close to the Bulgarian-Turkish border are both numerous and disturbing. When reporters interviewed one of the Bulgarian migrant hunters why he was involved in such an activity, he responded that the migrants he apprehended at the border on a weekly basis would only contribute to "slavery, rapes, mass rapes, [and] robberies of people" (Barker, 2016). Unfortunately, media exposure of the illegal attempts to cross the Bulgarian border and the rhetoric of some government representatives have been quite discouraging and detrimental to the humanitarian approach in helping resolve the crisis.

Comparative survey data suggests that prior to 2013 (the early stages of the Syrian refugee crisis), the main target groups of hate speech were Roma, Turks, and homosexuals. Surveys conducted in 2014 and 2016 demonstrate that Muslims and foreigners have become the frequent target of hate speech in the country. The proportion of respondents who claimed that they have heard statements of disapproval of Muslims increased from 10.6\% in 2014 to 38\% in 2016. A large proportion of respondents (31.1\%) associate the word "threat" with refugees and migrants (up from 9.4\% in 2014). Moreover, $18.7 \%$ of respondents also claim that they associate the word "criminal" with refugees and immigrants (up from 5.6\% in 2014). The progression of the migrant/refugee crisis seems to have exacerbated negative attitudes towards refugees and immigrants and Muslims in the country.

The refugee issue drew substantial attention in the months before the 2017 parliamentary elections. Most political parties put forth an exclusionary vision about their strategy of handling refugees and illegal migrants. The ruling political party the center-right Citizens for a European Development of Bulgaria (GERB) - advocated boosting security at Bulgaria's border with Turkey (Andonova and Angelov, 2017). The center-left Bulgarian Socialist Party (BSP) espoused an even stronger partialist position by arguing that refugees should not be allowed to settle in Bulgarian permanently (Andonova and Angelov, 2017). A representative of the nationalist coalition United Patriots stated that "we [Bulgarian politicians] are too concerned about the plight of the Syrians. Let us not forget that our own citizens live in our cities, and they have the right to decide whom they are willing to live with or not" (Andonova and Angelov, 2017). The coalition sided with the Socialists in contending that migrants and refugees should not be allowed to reside in the country. Several political parties embraced a more humanitarian approach to treating refugees or emphasized the importance of revising the Dublin regulation and seeking an EU-wide solution to the refugee and migrant crisis. The leader of the Movement for Rights and Freedoms, which represents the interests of the Bulgarian Turkish minority, argued that the Bulgarian government had to put more effort into integrating refugees in Bulgarian society (Andonova and Angelov, 2017). While there was a diversity of positions on the refugee issue, the official stances of the more established political parties reflected the majority public opinion more closely as they emphasized the importance of security and the need to reinforce Bulgaria's borders.

\section{Conclusions}

This study finds that the governments of Bulgaria and Hungary have both framed the migrant and refugee crisis caused by conflicts in the Middle East in security terms. Both Bulgarian and Hungarian policy makers and the media have emphasized images of refugees and migrants as vagrants, criminals, potential terrorists and extremists, and carriers of disease. This security frame has allowed the governments to formulate and execute policies that exclude refugees for being carriers of disease and security threat rather than welcome them as the vulnerable victims of political circumstances 
that are beyond their control. The Hungarian government's policy statements and media coverage have also focused on presenting refugees as a Hungarian cultural identity and heritage. Decisions taken by both governments were, to some extent, dictated by security concerns. The rhetoric of the Hungarian government, however, contained stronger nationalist overtones than that of the Bulgarian government. Hungary's Prime Minister Viktor Orbán and his right-wing government led an anti-migrant and anti-refugee campaign that sought to exclude foreign nationals due to the patent incompatibility of their cultural values with those of Hungary's nationals. On the other hand, the rhetoric of Bulgaria's Prime Minister Boyko Borisov - was more dualistic and contradictory. His policy statements to the foreign press or at EU summits reflected the general sentiment of the top EU brass, whereas statements made to the Bulgarian media focused more specifically on security concerns and were far more critical of the foreign nationals attempting to enter Bulgaria's territory. Moreover, the security-focused rhetoric and actions of the government became more strident immediately before and after the Bulgarian presidential elections of November 2016, which led to the resignation of Borisov's cabinet. Political parties in Bulgaria, including Borisov's GERB party have increasingly become critical of refugees living in Bulgaria's admission centers. Borisov's government even extradited a group of Afghan asylum seekers due to their involvement in a riot at one of the refugee admission centers. The present study demonstrates that while traditional theories of security studies dominate analyses of security challenges, these traditional theories cannot help explain how a given issue becomes 'securitized' and framed as a threat through elite rhetoric and media narratives. A non-traditional approach such as the one advanced by the Copehagen School of security studies sheds light on the securitization of human migration as seen in the refugee and migrant crisis caused by civil conflict in the Middle East.

\section{Acknowledgments}

The author acknowledges and thanks participants in the $49^{\text {th }}$ Annual Convention of the Association of Eastern European Eurasian and Slavic Studies and participants in the $69^{\text {th }}$ Annual Conference of the Political Studies Association for helpful comments and suggestions.

\section{References}

Assembly, U. N. (2016). Report of the Special Rapporteur on the promotion and protection of human rights and fundamental freedoms while countering terrorism. New York: UN General Assembly. Retrieved September 8, 2017

Baldwin, D. (1997). The Concept of Security. Review of International Studies, 23(1), 5-26. https://doi.org/10.1017/S0260210597000053

Belgrade Center for Human Rights (2016). Retrieved from http://www.bgcentar.org.rs/bgcentar/eng-lat/reports/ Accessed December 2, 2019.

BG Novinite (2014, December 27). "Bulgaria izdigna "zlatna" ograda ot bodliva tel po granicata s Turcija". BG Novinite. $\quad$ Retrieved October $30, \quad 2016$, from http://btvnovinite.bg/article/bulgaria/balgarija-izdigna-zlatna-ograda-ot-bodliva-tel-po-granicata-s-turcija.html

Bigo, D. (2002). Security and immigration: Toward a critique of the governmentality of unease. Alternatives, 27(1_suppl), 63-92. https://doi.org/10.1177/03043754020270S105

Bordermonitoring Bulgaria. (2017, October 28). Retrieved from Bordermonitoring Bulgaria: http://bulgaria.bordermonitoring.eu/statistics/

BTA. (2015, October 24). Premier says Bulgaria, Serbia, Romania ready to close borders over refugees. BTA.

Bulgarian Helsinki Committee (2016). Retrieved from https://www.bghelsinki.org/media/uploads/annual_reports/annual_bhc_report_2016_issn-2367-6930_bg.pdf

Buzan, B., \& Hansen, L. (2009). The Evolution of international security studies. Cambridge: Cambridge University Press. https://doi.org/10.1017/CBO9780511817762

Buzan, B., Waever, O., \& de Wilde, J. (n.d.). Security: A New Framework for Analysis.

Caviedes, A. (2017). Media Agents. In P. Bourbeau (Ed.), Handbook of Migration and Security (pp. 296-315). Northampton, MA: Edward Elgar. https://doi.org/10.4337/9781785360497.00025

Cochetel, V. (2008). UNHCR presentation to the Joint Seminar of the Strategic Committee on Immigration, Frontiers and Asylum (SCIFA) and Committee on Article 36 (CATS) organized by the Slovenian EU Presidency. Ljubljana. Retrieved October 23, 2017, from http://www.refworld.org/pdfid/4794c7ff2.pdf

Csuhaj, I., \& Horváth, G. (2015, September 9). Foreign minister sees international media campaign against Hungary, Macedonia . Népszabadság.

Czene, G. (2016, March 7). Hungarian far-right group holds conference on protection of "white human race". Népszabadság. 
D'Appollonia, A. C. (2012). Frontiers of Fear: Immigration and Insecurity in the United States and Europe. Ithaca and London: Cornell University Press. https://doi.org/10.7591/cornell/9780801450686.001.0001

D'Appollonia, A. C. (2017). Xenophobia, racism and the securitization of immigration. In P. Bourbeau, Handbook on Migration and Security (pp. 252-272). Cheltenham, UK: Edward Elgar Publishing.

Emmerson, $\quad$ B. $\quad$ (2016, $\quad$ September 13). Retrieved from https://documents-dds-ny.un.org/doc/UNDOC/GEN/N16/285/61/pdf/N1628561.pdf?OpenElement

EUROPOL. (2017). Retrieved September 13, 2017, from EUROPOL: https://www.europol.europa.eu/activities-services/main-reports/eu-terrorism-situation-and-trend-report

Fekete, A. (2015, September 23). Hungarian secret services investigate ringleaders of migrant demonstrations. Népszabadság, p. 3.

Funk, M., \& Parkes, R. (2016, January). Refugees versus Terrorists. European Union Institute for Security Studies.

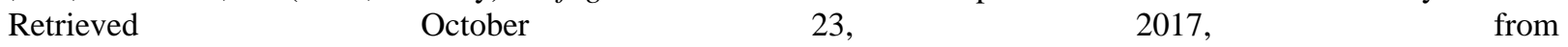
http://www.europarl.europa.eu/greece/resource/static/files/refugees-versus-terrorists.pdf

Gall, L. (2015). Dispatches: Hungary's Anti-Migrant Fence is an Insult to Its History. Retrieved from https://www.hrw.org/news/2015/06/22/dispatches-hungarys-anti-migrant-fence-insult-its-history Accessed December 2, 2019.

Gjorv, G. G. (2012). Security by any other name: negative security, positive security, and a multi-actor security approach. Review of International Studies, 835-859. https://doi.org/10.1017/S0260210511000751

Hansen, L. (2012). Reconstructing desecuritisation: the normative-political in the Copenhagen School and directions for how to apply it. Review of International Studies, 38, 525-546. https://doi.org/10.1017/S0260210511000581

Hargitai, M. (2016, March 10). Hungarian daily slams public media for inciting fear with refugee issue coverage. Népszabadság, p. 9.

Herţa, L. M. (2017). Security as Speech Act. Redefining Community in Intercultural Context, 6(1), 283-287.

Human Rights Watch. (November 23, 2016). EU Policies Put Refugees at Risk. Retrieved December 2, 2019, from https://www.hrw.org/news/2016/11/23/eu-policies-put-refugees-risk\#

Népszabadság. (2015, December 14). Hungarian analysts say ruling party becomes more centralized, united. Newpszabadsag, p. 3.

Népszabadság. (2015, July 6). Hungarian far-right party calls for self-defence against immigrants. Népszabadság, p. 3.

Népszabadság. (2016, March 16). Hungarian PM uses anniversary speech to gain support for foreign policy. Népszabadság.

Newland, K. (2015, October 7). The U.S. Record Shows Refugees Are Not a Threat. Retrieved October 23, 2017, from Migration Policy Institute: https://www.migrationpolicy.org/news/us-record-shows-refugees-are-not-threat

Papakochev, G. (October 12, 2016). Niakoi pokrovitelstva bulgarskite kanaldzhii. DW. Retrieved December 2, 2019, from https://www/dw.com

Simonovits, B., \& Bernat, A. (2016). The Social Aspects of the 2015 Migration Crisis in Hungary. Budapest: TARKI Social Research Institute. Retrieved October 17, 2017, from http://www.tarki.hu/en/news/2016/items/20160330_refugee_en.html

Strickland, P. (2016). Refugee Crisis: Hungary Sends More Troops to Border. Al Jazeera, 10 March 2016. Retrieved from http://www.aljazeera.com/news/2016/03/refugee-crisis-hungary-sends-troops-border-160309134453267.html

Taylor, A. (2017, August 1). An Anti-immigrant group mistook empty bus seats for women wearing burqas. Retrieved from The Pashington https://www.washingtonpost.com/news/worldviews/wp/2017/08/01/how-a-photo-of-empty-bus-seats-triggere

UNHCR - Europe Situation. (2017, August 28). Retrieved from UNHCR: http://www.unhcr.org/en-us/europe-emergency.html

Waltz, K. (1979). Theory of International Politics. Reading, MA: Addison-Wesley. 


\section{Appendix A}

Coding instructions for content analysis of newspaper articles published in the Bulgarian and Hungarian print media (January 1, 2015 - August 31, 2017)

\begin{tabular}{|c|c|c|}
\hline Variable & Content & Operationalization \\
\hline Day & Day of publication & Values range between 1 and 31 \\
\hline \multirow[t]{2}{*}{ Country } & Country of publication & Bulgaria $=1$ \\
\hline & & Hungary $=2$ \\
\hline \multirow[t]{2}{*}{ Month } & Month of publication & January $=1$ \\
\hline & & December $=12$ \\
\hline \multirow[t]{3}{*}{ Pol_asylum } & Does the article mention a policy & $\mathrm{No}=0$ \\
\hline & that emphasizes change(s) to & Yes $=1$ \\
\hline & asylum procedures? & \\
\hline \multirow[t]{3}{*}{ Pol_det } & Does the article mention a policy & No $=0$ \\
\hline & that emphasizes detentions of & Yes $=1$ \\
\hline & refugees? & \\
\hline \multirow[t]{3}{*}{ Pol_expel } & Does the article mention a policy & $\mathrm{No}=0$ \\
\hline & that emphasizes expulsions of & Yes $=1$ \\
\hline & refugees? & \\
\hline \multirow[t]{3}{*}{ Pol_phys } & Does the article mention a policy & No $=0$ \\
\hline & such as the construction of a & Yes $=1$ \\
\hline & physical barrier, wall or fence? & \\
\hline \multirow[t]{3}{*}{ Sec_threat_econ } & The article makes a reference to & No $=0$ \\
\hline & refugees as a source of threat to the & Yes $=1$ \\
\hline & economy of a country. & \\
\hline \multirow[t]{3}{*}{ Sec_threat_ter } & The article makes a reference to & $\mathrm{No}=0$ \\
\hline & refugees as a source of terrorist & Yes $=1$ \\
\hline & threat. & \\
\hline \multirow[t]{4}{*}{ Sec_threat_cul } & The article makes a reference to & No $=0$ \\
\hline & refugees as a source of threat to the & Yes $=1$ \\
\hline & religion or cultural identity of the & \\
\hline & country. & \\
\hline \multirow[t]{2}{*}{ Source } & Which news source was the article & $\mathrm{BTA}=1$ \\
\hline & published in? & Népszabadság = 2 \\
\hline \multirow[t]{3}{*}{ Year } & Year of publication & $2015=1$ \\
\hline & & $2016=2$ \\
\hline & & $2017=3$ \\
\hline
\end{tabular}

\section{Copyrights}

Copyright for this article is retained by the author(s), with first publication rights granted to the journal.

This is an open-access article distributed under the terms and conditions of the Creative Commons Attribution license (http://creativecommons.org/licenses/by/4.0/). 